\title{
ACHIEVING GRADUATE COMPETENCY STANDARDS: IMPACT OF THE EXCELLENCE PROGRAM
}

\author{
Agus Zaenul Fitri \\ Institut Agama Islam Negeri (IAIN) Tulungagung \\ Jl. Mayor Sujadi Tim. No.46, Kudusan, Plosokandang, \\ Kedungwaru, Kabupaten Tulungagung, Jawa Timur, Indonesia, 66221 \\ Email: guszain@yahoo.co.id
}

Received: 06, 2017. Accepted: 06, 2018. Published: 06, 2018.

\begin{abstract}
The purpose of this paper is to reveal the results of the efforts and strategies to improve the quality of graduates in achieving competency standards in FTIK (Fakultas Keguruan dan Ilmu Pendidikan/Faculty of Education and Teacher Training) at The State Islamic University of Malang, Indonesia. The existing challenge today, namely the ASEAN Economic Community (AEC) in which the human resources with special requirements, is to be able to compete and work at any positions wherever they want. An Islamic college, particularly the FTIK where the prospective educators are "born", should be able to produce graduates who have both national and international qualifications. As a result, it demands the necessary management and strategies to achieve SKL (Standar Kompetensi Lulusan/ Graduate Competency Standard). This study uses qualitative approach with field research type. Strategies to guarantee the quality of graduates done through tight assessment, provision of extra programs that can improve the students' academic quality, continuous assessment, and the students' scientific work must be written in either English or Arabic. Excellence program has a positive impact either on students who want to continue to pursue higher education or students who choose to work. The graduates of excellence programs are proven to have tough mentality as well as high work ethics.
\end{abstract}

Keywords: Quality, Graduate Competency Standards, Excellence Program.

\begin{abstract}
ABSTRAK
Tujuan makalah ini untuk melaporkan basil penelitian tentang berbagai upaya dan strategi peningkatan kualitas standar kompetensi lulusan di Fakultas Keguruan dan Ilmu Pendidikan (FKIP) UIN Malang. Pemberlakaun program Masyarakat Ekonomi Asean (MEA) menuntut sumber daya manusia dengan keterampilan kbusus agar mampu berkompetisi dan bekerja dimana saja dengan posisi yang mereka inginkan. Institusi pendidikan Islam, kbususnya FKIP, harus mampu melahirkan lulusan-lulusan yang mempunyai kualifikasi nasional dan internasional. Sebagai konsekwensinya, lembaga pendidikan membutubkan strategi dan manajemen penting untuk mencapai standar kompetensi lulusan (SKL). Penelitian ini menggunakan pendekatan kualitatif dengan studi lapangan. Adapun strategi untuk menjamin kualitas lulusan dilakukan dengan asesmen yang ketat, pengadaan program-program ekstra untuk. meningkatkan kualitas akademik. lulusan, asesmen berkelanjutan dan juga tugas mabasiswa yang ditulis baik dalam bahasa Inggris maupun bahasa Arab. Program unggulan mempunyai dampak positif baik, terbadap mahasiswa yang mau melanjutkan studi di program magister ataupun yang mau melanjutkan kerja. Lulusan dari program unggulan terbukti mempunyai mental yang tangguh dan juga etos kerja yangn tinggi.
\end{abstract}

Kata Kunci: Kualitas, Standar Kompetensi Lulusan, Program Unggulan.

\section{INTRODUCTION}

The quality of education which is work-oriented has become a crucial need (Barnett, 1992) for every country, including Indonesia. PTKIN (Perguruan Tinggi Keagamaan Islam Negeri/State College for Islamic Religious Affairs) such as IAIN (Institut Agama Islam Negeri/State Islamic Institute) and UIN (Universitas Islam Negeri/State Islamic University) is a sub system of national 
education that cannot be separated from this demand. Having qualified lecturers, up to date curriculum, adequate infrastructure, representative library and laboratory are parts of the expectations of the society towards PTKIN. People expect that PTKIN can be a strategic place for the development of human resources that can produce graduates who have the knowledge and skills required by industry (society). In a global context, Islamic higher education is "demanded" to correct the bad image of Islam and Muslims, particularly in the West world (Mostafa, 2007). It is unfortunately common that people know Islam and a religion of terror as so many Muslims are portrayed as suicidal bombers in the name of "jihad". Therefore, having Islamic higher education graduates with good competences is inevitable.

In addition, universities in Indonesia still face other problems because of late responses in the development of information and technology (Fitri, 2016, p. 209). Efforts to improve access, quality and relevance in higher education require increased resources and improved stewardship of resources in both the private and public sectors (Ramirez \& Berger, 2014, p. 100). Qualified higher education should at least be able to meet the needs of stakeholders, such as: (1) social need; (2) industrial needs; and (3) professional needs. A deep understanding to what is required by the users of the educational services will lead the educational institution to be able to achieve the results in accordance with its vision and mission.

Efforts to create such linkages are referring to the Tri Dharma Perguruan Tinggi (three missions of higher education), including education and learning activities, research activities as well as community services. The three missions of universities state that it needs to evaluate the relevance of programs and majors in every unit of educational institution whether or not they correspond to the needs of national development in a case that the product of the institution could be used to run the economic and development of the nation. It requires a special strategy to achieve these demands. First, the raw input and instrumental input; raw input is learners while instrumental input consists of buildings, library, academic guidance, faculty, curriculum, methods and others. Second, raw input and instrumental input in the learning process which take eight semesters of averages. Third, output or graduates who have the criteria requires by the institution and who are ready to enter the competition in the real world, namely the labor market. Lecturers are instruments that determine the success of the educational process due to their function to transfer knowledge to the students. In any other sense, to improve the quality of learning in the classroom demands good lectures as well as the program and development undertaken by the leader at the faculty level.

Universities which have qualified lecturers will be much preferred by the public since they assume that the quality of learning is likely to increase by those qualified educators. Consequently, the program to improve the quality of the lecturers is an obligation that is not negotiable in the present and/or in the future. Higher education or universities which do not follow current or future development surely will be abandoned by its society and sooner or later will suffer a setback which would eventually meet extinction or a collapse.

On the other hand, the curriculum is a set of plans and arrangements regarding the content and study materials as well as teaching and assessment strategies which are used as guidelines for the implementation of teaching and learning in higher education (Fullan \& Pomfret, 1977). The curriculum is divided into two namely core curriculum and local curriculum. Core curriculum is a part of the curriculum of higher education that is nationally applicable for each program of study which consists of educational objectives, content knowledge, and the standard minimum that must be achieved by the learners in the completion of a certain course study. Meanwhile, local curriculum is a part of the curriculum of higher education with regards to the circumstances and needs of the environment as well as the hallmark of the universities. 
The development of curriculum in PTKIN should be carried out at least 2 years in order to anticipate and address the demands of the society and the changing of times. Islamic education should adapted as a response to the times (Syahputra, 2013, p. 78). Innovation and development of Islamic education curriculum needs to be done due to some criticisms towards Islamic education curriculum in PTKIN, among others: (1) it is overload, meaning that there are too many subjects included; (2) it focuses only on the mastery of methods and learning strategies, but it is weak in core materials mastery, such as Fiqh, Ușūl al-Fiqh, alQur'an, Hadith, and the History of Islamic education and civilization; (3) it is cognitive masteryoriented but less applicable; (4) the understanding towards the essence of Islam is limited; (5) PAI (Pendidikan Agama Islam/Islamic Education) learning is less attractive; (6) the implementation of Islamic education is still proprietary and have not been able to interact and sync with others (Fitri, 2013, pp. 90-91).

The more concern problem is the changing orientation of FTIK, formerly known as Islamic educational faculty (tarbiyah) which offered more Islamic studies in the SKS (Satuan Kredit Semester/Credit Hours), but now presenting more educational studies that in turn resulted the students who master more on the concept of didactic methodology (learning models, learning strategies and learning methods) than the mastery of Islamic science like al-Qur'an, Hadith, Aqidah, Fiqh and the History of Islam. It is surely does not in relation with the former teaching and learning goal that is to produce Islamic teachers who master the material on PAI.

Based on the statement of one of the professors, the current remarkable shift is not only caused by the curriculum but also caused by the lecturers recruitment factor within a decade that was more dominated by the graduates of non-Islamic college, either the S1 (bachelor) or S2 (master) degree, so that they do not understand about Islam deeply. Finally, they just emphasize on the teaching of theoretical aspects of educating only (personal inteview. Interview/MKY/UIN Malang/27 Nov 2014). It is very different from the expectations and ideas of the beginning establishment of FTIK itself. Based on preliminary observations, it was found that there were 6 out of 10 students whose ability and mastery of the Islamic science were still quite low, such as the ability to read and write Qur'an, as well as the mastery of the concept of Islam (O/Comprehension Examination/IAIN Tulungagung/2014-2015). Other preliminary data also showed that the students' mastery was only focused on Fiqh and Qur'an-Hadith (interview and hearing with the heads of the MTs/MTsN and MA/MAN in Tulungagung year 2013/2014).

In addition to the above issues, PTKIN are also required to be able to respond the user need in producing its graduates. There are some questions such as whether or not college can guarantee its graduates to the users? Does college provide a guarantee for its graduates' quality? Have the graduates reached out the Graduates Competency Standard (SKL)? Of course, the answers can vary.

Facing problems and challenges as above, there are some PTKINs which are doing progressive and making efforts through a program called excellence program by holding special classes for students who have special abilities who are also projected to become graduates with certain abilities in the future. This program is expected to produce excellent human resources who will be useful to build the nation. It is undeniable that parents want their children to be superior or excellent. It can be seen from the public interest to enroll their children to a good university. Every year, university with its excellent program is always flooded by prospective students. They believe that they will become excellent students by entering this university.

An important point is that PTKIN faces a challenge of creating qualified output and getting the students as the raw input. These two challenges are interrelated issues if are approached by an approach which is called as system approach. In the system-approach perspective, there are at least three subsystems of education that are interrelated. They are 
input, process and output (Waridjan et.al, 1984, pp. 4-6). To produce outputs that are qualified, educational process as the interaction of various inputs including raw input (students) and instrumental input (faculty, curriculum, methods/ strategies, infrastructure, and others) must also be qualified. Furthermore, the educational process will be qualified when the input involved in the learning interaction are also qualified. One of the inputs that will determine the quality of the process is a raw input (students). Having qualified raw inputs, the educational process will run more effectively and efficiently, which in turn will produce a qualified output.

To get good raw input, of course, it is related to the amount of applicants who apply in the university. The high number of applicants will give the more chances for the school to select superior inputs. Moreover, the selection level will be tougher so that the student who passes the selection is the participant who is not only has good quality but also has a good academic idealism.

Producing good output can be done if there is learning process that has good quality ranging from: (1) the quality of lecturers in preparing teaching materials, (2) a curriculum to improve the competence and professionalism of students, (3) learning facilities; (4) the source and medium of learning, (5) approaches, strategies and methods used in the class, and (6) an enabling environment that can support successful learning. Alfian (2011) concluded that some efforts to improve the quality of learning are enhancing student creativity, establishing discipline, and increasing motivation. In the meantime, good learning indicators comprise (a) teacher mastery of the learning materials; (b) finished teaching and learning processes; and (c) development of student understanding.

The expected additional value resulting from this study was the determined curriculum and innovative learning in PTKIN to improve the graduates' quality and competitiveness in order to meet the needs of society. Therefore, one way to answer this question is by doing curriculum development in PTKIN that has the orientation to achieve the Graduate Competency Standards. It must be responded by updating the curriculum that suits the need of the society and the dynamics of the society. Finally, based on the above problems, this research is important to be carried out.

This research is carried out to dig the aspects related to teaching strategies for quality improvement to achieve the Graduates Competency Standard in PTKIN remembering the shift orientation of education that is to produce the graduates that meet the needs of stakeholders as well as the graduates who have knowledge and skills as future professional educators with the spirit of Islam.

Due to the wide extent of the fields in FTIK UIN Malang, this study is only focused on the following research questions: 1) How is the effort for learning quality improvement to achieve the SKL in FTIK UIN Malang? 2) How is the effort to improve the quality of lecturers for learning quality improvement to achieve the SKL in FTIK UIN Malang? 3) How is the strategy to ensure the quality of the graduates in FTIK UIN Malang? and 4) How is the implication of the excellent program to the graduates in FTIK UIN Malang?

\section{METHOD}

The study used a qualitative approach to explore and dig the phenomena or social reality by describing a number of aspects relating to the problem being investigated. This study aimed to get a deep and directed description of improving the quality of learning to achieve the SKL. The setting of the study was at UIN Maulana Malik Ibrahim Malang.

The researcher collected data based on information and observations in the situation that was reasonable and friendly as what it is at usual. The data in the study were collected using some techniques, namely: (1) participatory observation, (2) in-depth interviews, and (3) 
documentation study (Bogdan \& Taylor, 1992, p. 65). Data analysis technique in this study was qualitative descriptive technique that was done inductively.

\section{RESULTS AND DISCUSSION}

\section{The Efforts for Learning Quality Improvement to Achieve the Assigned SKL in FTIK UIN Malang}

UIN Maliki Malang took the input by means of a rigorous selection. The use of Arabic and English as a means of communication at the class was enacted to ensure a good quality of learning process. There were not $100 \%$ of lecturers who are capable of using foreign language, but it was at least $70 \%$ of foreign languages have been used by the lecturers to guide the learning process. They hoped that in the future all the lecturers would be able to use the international languages in the learning process. In the learning process, FTIK also provided an opportunity for students to participate in the selection of PPL (Praktek Pengenalan Lapangan/Teaching Practice Program) held in foreign countries such as Malaysia and Thailand. They were selected based on their ability in teaching as well as their capabilities and mastery of both Arabic and English. It is important for the students (graduates) to be able to compete in the era of globalization with other students from all over the world. To be able to do that, one of the most important skills is language. As a means of communication, an international language is a must. Two of the most popular international languages are English and Arabic. In Islamic higher education, those two languages should be mastered by the students. Being bilingual is a good skill for students and graduates in this competitive world (Findlow, 2006).

One of the ways to achieve the SKL was set particularly on the ICP (International Class Program) that each student was required to write a graduate thesis in Arabic or English for PAI majors, while majors such as PGMI (Pendidikan Guru Madrasab Ibtidaiyah/Islamic Primary Education Departement) and other such as social studies were only required to write in English only.

Graduate Competency Standards (SKL) was an integral part of education because it was a determinant of learning path. As described in cha pter two, one of the SKL goals was to provide a reference in formulating the criteria, the basic framework of quality control and assurance for graduates. Therefore, the learning process was directed to achieve a predetermined SKL.

The need for qualified human noticeably increases in this era of globalization. It suggests that education in its various programs has an important role in the process of obtaining and improving the quality of human resources who has a superior ability and good character.

The success or failure of education to produce qualified outcomes will also be determined by the human factor as a sub-system that will also influence the educational success in achieving the best quality of graduates who are expected to become the human resources needed (Carter, 2004). As the driving agent of change, the human resources required to be able to overcome all the challenges and are expected to take advantage of the opportunities and to meet the needs of the society.

The development of qualified education is largely determined by the quality of the learning process. Based on this point, there are several important factors, among of them are: the quality of lecturers, materials (curriculum), sources and media of learning as well as other supporting factors. Education and learning is the best way to develop intellectual abilities and personalities which must be carried out professionally and continuously. An old theory regarding lectures, lecturers, and the lectured, states that a lecturer should know what a lecture is as well as be able to listen to others to be considered a good lecturer (Trott, 1963).

The results of the study showed that one of the efforts to improve the quality of learning is the quality of lecturers. Lecturers are placed in accordance with their expertise. This is in line 
with the idea of Herliana who revealed that the quality of learning is influenced by: 1) the ability of teachers in implementing the curriculum and using teaching methods that are effective to create a good atmosphere of learning through multi directional interaction; 2) the ability of teachers to seek and develop new knowledge about the various methods of learning both as individuals and as an initiative of a collective effort between teachers; 3) ability to reflect on the learning and to design teaching model as well as implement the appropriate corrective learning that relevant to the learning methods (Herliana, 2003, p. 5). Based on these descriptions, it can be understood that if you want to get qualified learning; you should have qualified lecturers as well.

However, having qualified lecturers are still not enough if the students who are guided have low quality. Lecturers will have difficulty in teaching. Based on the findings, it indicates that it needed for separation between students who have more capability with those who have average ability to maximize the learning process. Separation is done by conducting placement test with the main requirement GPA (What is GPA) is of 3.00. With the combination of qualified students and qualified lecturers, it is expected to achieve a superior level of learning. This supports a research finding stating that lecturer-student relationship is an important bonding in high quality education. Therefore, insights from both lecturers and students are such a good contribution in a success of education (Makondo \& Ndebele, 2014).

The fact also reinforces the Sergeovani's idea which states: "An excellent school is where uniform and high academic standard are able to perform up to these standards as evidenced by scores on criterion referenced or other tests." (Maimun \& Fitri, 2010, pp. 22-23). It also reinforces the explanation in chapter 2 which states that the institution can be said to be excellent when the image of the institution or the program provided is characterized by a strong commitment to achieving the goals which marked by the learners who has been evaluated using standardized tests as well as their ability to show their intelligence in many other ways. In other words, the institution may be called superior if the students are able to achieve high academic achievement, have responsible community awareness, have moral and ethical, are able to express the values of beauty, and are emotionally and physically good.

Having qualified students would be pointless if the treatment given is the same as that to regular students. The findings showed that small classes come with higher capability. Each class consisted of 20 to 25 students. The assignment was more varied and many. It was not just writing a paper then being presented, but also creating articles in blogs as well as doing practicum, etc. In addition, the students were required to use either English or Arabic in any learning activities and assignments. The learning program was not merely occurred in the classroom, but there were also extra programs that could support to improve the academic quality of students, such as student day, short course for TOEFL ITP, language tutoring given to students around the region, Learning Center, etc. This is in line with a finding of previous study (Mitchell, 1969) that small classes are: 1) Necessary especially when the program is specific; 2) Able to decrease diverse effect and to keep the stamina of the teachers; 3) Supportive towards innovations; and 4) Efficient for an activity-oriented program.

The findings indicated that the quality of the lecturers is a major consideration in the recruitment and placement. In addition, the students as the main part of the learning process were distinguished between the more capable students with the average students (lower and higher achievers) so that the learning process could be maximized. They believed that in order to achieve the predetermined SKL, learning merely in the classroom was not enough. They, then, took a few programs that could improve the students' competency.

In relation with lecture quality, Higher education has been the concern for the government to handle with in terms of lecture quality development. It requires a brand new paradigm on the part of the government to deal with higher education lecture development. On the part of the 
government, various efforts have been made by employing three major projects to boost the quality of teaching and learning at universities and quality of its graduates. The three projects initiated by the government cover: 1) the development in undergraduate education project (DUE); 2) the quality in undergraduate education project (QUP); and 3) the engineering education development project (EED) (Idrus, 1999).

\section{The Efforts to Improve Lecturers Quality at FTIK UIN Malang}

Lecturers have a major influence on the improvement of learning process. It required qualified lecturers to be able to improve the quality of learning. Based on the findings, FITK UIN Maliki Malang showed the efforts in improving the quality of lecturers. The faculty wanted all lecturers not only had expertise in their field but also had skills to communicate using foreign language as well as had a deep understanding towards Islamic knowledge and value. To motivate the lecturers to have an awareness especially to always improve their competence, the faculty provided variety of programs, one of them by presenting the lecturers from other countries to share their knowledge through discussion forums.

Due to the ICP program that the FTIK had, all lecturers and employees were given an opportunity to develop their language skills through cooperation with IALF in Bali. The activity was conducted within two months to train the lecturers and employees so that they were skilled in English. It was in line with the vision of the university that wanted to become a Word Class University (WCU). Before they have such cooperation with IALF, FTIK also had been cooperating with the Education First (EF) to improve lecturers' language skills.

Such programs were a part of an effort to develop the quality of the lecturers. It is also a kind of program that is dedicated for fulfillment of the obligations contained at Law No. 14/2005, 2005 on Teachers and Lecturers which states that:

The Government shall foster and develop academic qualifications and competence of lecturers in higher education units held by the government and/or community. Higher education units held by the public shall foster and develop the lecturers' academic qualifications and competence.

Management of human resources in higher education, especially for professors/lecturers, needs to be directed at the empowerment of the lecturers themselves which focused on the empowerment to improve the quality of the educational institutions. It certainly has to start with an idea, as logical foundation, that teachers have to be able to contribute themselves to the educational institutions. The lecturers' paradigm should begin by conducting contemporary educational orientation, which includes: First, from temporary learning to lifelong learning; Second, from learning to focus on the acquisition of knowledge to holistic learning; Third, change the image of the relationship between lecturer and student from confrontational relationship to partnerships; Fourth change the orientation of teaching that emphasizes on academic knowledge to the accentuation of moral and value; Fifth, change the conventional teaching to the teaching that utilizes information technologies (IT) and cultural approaches. Sixth, lecturers' look that is from individually to team work.

It is expected that by the existence of lecturers whose paradigm as said above, educational institutions, in turn, can face the competitive challenges that impacted on the emergence of comparative advantage of the educational institution in the middle of society. As a consequence, the school or educational institution must provide and organize a good mechanism for selecting its human resources.

Good mechanism of human resource management can be seen as follows: First, the recruitment system. Second, take a look at the lecturers' cognitive competence as well as their ability to adapt with culture and academic system applied in the institution. There are many cases 
where the educational institutions have good human resources, but they are not good enough in obeying the system or rules that have been set by the educational institution. It is mostly justified that a lecturer has independence in providing teaching and training to students. Therefore, it is expected that in the process of managing the human resource, the equalization of perception between school value (culture) and lecturer's idealism is always be nurtured by means of effective communication at every opportunity (Beare, Caldwell, \& Millikan, 2018). Why does it need to be done? It is because miscommunication usually leads to prejudice and establishes false assumptions to the purpose of human resource (lecturer) management.

Third, the way the educational institution controls the process of teaching and learning activities conducted by the lecturers. To measure to what extent the conception of education and teaching has run effectively, the lecturers in educational institutions must also be monitored to measure their performance and productivity. Fourth, the way the education institution give award to the lecturer who has given positive contribution for the institution.

Duties and responsibilities of a lecturer, the requirements to become a qualified lecturer, how to evaluate the quality of lecturers, the role of either the leaders, the employees or the lecturers for continuous improvement of lecturers quality, is a matter that absolutely need to be emphasized by an institution in higher education. All these things need to be understood and implemented by all of the academic community to achieve the vision and mission of the institution. By continuous lecturers' quality improvement, it is expected that the institution will be able to win the competition both in the present and in the future. As consequence, it needs to be emphasized on how the role of the lecturer in the learning process, how lecturer should develop themselves to become qualified lecturer, how lecturer should conduct sustainable selfevaluation, and many others (Darling-Hammond \& Lieberman, 2013).

Lecturers in higher education are human resources for the institution and they have prominent role and strategic one in higher education enterprises. Their role is explicitly stated in the Law Number 20 Year 2003 on National Education System, Law Number 14 Year 2005 on Teacher and Lecturer in Higher Education and Ministerial Regulation Number 42 Year 2007 on Lecturer Certification. Their quality plays important role in determining both high and low quality of the future generation in the country. Therefore, since 2009 the government has initiated and offered scholarship program the so-called Academic Recharging Program for lecturers with Doctor qualification, Professors, graduate and postgraduate managers, and Coordinator of Islamic higher education institution officials. The program has been taken into consideration because of the fact that lecturers and professors with long service tenure in higher education need to be recharged and boosted in terms of their academic skill and motivation. To do so, the government sends recipients of academic recharging program into several universities overseas (Dirjen Dikti, 2017).

\section{The strategy to Ensure the Graduates Quality in FTIK UIN Malang}

The research findings indicated that strategy of FTIK UIN Malang to ensure the quality of its graduates is through conducting a series of programs that can be used to measure the student ability. They were TOEFL ITP, regular evaluation, study guidance from the supervisor, and many other extra-curricular programs as supporting activity for their academic improvement and in order to provide a chance for the students to apply their obtained knowledge. In addition, the lecturers were also being tested regularly to measure their core competence since the beginning of the semester.

Education is a public institution which provides a service. As a public service institution, it required a guarantee for the graduates to hold a trust from the people who use these services. Therefore, it needs necessary strategies to produce the graduates who have good quality so that it does not disappoint the public. 
Based on research finding, it is known there were various strategies that were done to ensure the quality of graduates produced. The strategy was not only in term of evaluation, but also included the learning process and supervision. In evaluation, there was a competency test conducted each semester to determine and quantify the extent of competencies achievement that has been set. There was also supervision as a means of learning evaluation. This is in accordance with one of the elements that should be owned by the excellent educational institution namely good and measurable learning evaluation. Good evaluation is the evaluation that based on the reference standard to determine whether or not the learning objectives have been reached. If the curriculum has been set neatly and clearly, the goals of learning could be identified and measured so that it was able to map the students' abilities (Cronbach, 2000).

The ability to manage and develop the higher education has been very necessary, including using the principles of modern management that is quality-oriented. For the owners and managers of universities, quality management system is essentially administered on continuous improvement and quality assurance (Burnham, 1997, p. 359). To ensure that the learning process is carried out to reach the expected quality, it required quality control and quality surveillance (inspection) (Burnham, 1997, p. 18). Moreover, according to Deming, in TQM (Total Quality Management) it is required TQC (Total Quality Control) in an attempt to control the quality (Heryanto \& Mabnun, 1993, p. 11). Economic and monetary crisis as well as the free market requires us to be more careful in determining our future act fore based on the consideration of potentials, obstacles, opportunities and threats.

One indicator of the quality of outputs (graduates) can be seen from their final project in the preparation of the thesis. As an undergraduate, the thesis is considered as the toughest scientific work for not only S1 students, but also S2 and S3 students. The quality of thesis is determined not only by students, but also by the quality of the supervisor as well as the guidance process.

Coaching or tutoring consisted of two kinds, namely (a) the academic guidance and (b) thesis writing guidance. The characteristic of qualified academic tutoring lies in the ability to explore the students' academic potential so that students can follow the academic provisions that always being consistent with their objectives to study at the college.

\section{The Implication of the Excellent Program to the Graduates in FTIK UIN Malang}

The findings showed that excellence program embodied in the ICP program gave an impact on the graduates' mentality. Armed with good academic quality and ability in Arabic and English, the students of ICP have high ideals and spirit to achieve their dream. It was proven by the students who obtained scholarship to continue their study in foreign universities. In addition, the graduates of ICP program had more confidence than the other regular programs due their skill in mastering foreign language that able them to compete with the people outside the country.

Excellence program had a positive impact on graduates who participated in the program. The results showed that the graduate of excellence program had a strong mental and work ethic. They were also more likely to continue their study at a favorite institution, even in educational institutions abroad. The findings also demonstrated the successful achievement of the purpose of the excellence program.

Thus, the excellence program is expected to create the nation's generations to promote the education in Indonesia. Superior generation is basically measured by the ability of learners academically, as proposed by Sergeovanni as quoted by Agus and Maimun: An excellent school is and image of schooling where uniform and high academic standard are able to perform up to these standards as evidenced by scores on criterion referenced or other tests (Maimun \& Fitri, 2010, pp. 22-23). 
Based on the above statement, the institution may be called superior if the students are able to achieve high academic achievement, have social responsibility awareness, have good moral and ethical, are able to express the values of beauty, and are emotionally and physically good.

In relation to the characteristics of the five above competencies, it can be inferred the three trends occur: a) the knowledge and skill tend to be more real (visible). Therefore, it is relatively easy to be developed so that the training program is a good way to ensure a level of human capability; b) motive competency and trait is the personality iceberg, so it is quite difficult to be assessed and developed so that one of the most effective ways is to choose those characteristics in the selection process; c) self-concept, trait (character) and motive competence are more hidden, deeper and located at the central point of one's personality. The self-concept is located between them. While, attitudes and values as self-confidence (seeing one's self as a "manager" instead of a" technical/professional) can be changed through training, psychotherapy even sometimes it takes long hard time (Maimun \& Fitri, 2010, pp. 19-20).

Seeing a trend described above, it can give an idea for the managers on how to plan and develop the strategy for improving the quality of the future human resources. These characteristics are mutually determined each other. Based on the characteristics of competence above, the implication of excellence program has given a positive impact to students in terms of motivation to learn and continue their education at the college abroad. The graduates of ICP program were also have more confidence. Their gained knowledge and skills were also better than others who were at regular programs.

One of the indicators of a good school is a good graduate and one of the indicators of a good graduate is where they work after school. In Nigeria, for instance, a study proved that a good graduate mostly has a good career. When their academic performance is good, they usually work in universities or other academic-related places such as laboratories, research centers, etc. However, when the graduates showed good social and organizational at school, they become good businessmen and politicians (Okwu, 2006). In the meantime, a study conducted in the US showed that it is important for universities and schools to pay attention to the pressure and stress each student has when they are enrolling in their schools. Their unhealthy body and mind when studying could actually contribute to their lack of self-esteem and later failure when they build their career after graduation (Ogunsanya, et. al., 2018).

\section{CONCLUSION}

The effort to improve the quality of learning is done by improving the quality of the learning process. It is supported by the goal standard which is higher than those at regular program. Paper writing and presenting are using of English and Arabic. In addition, the standard quality of assessment is also higher. To improve the quality of lecturers is done with a variety of program to develop the lecturers' competencies and skills, particularly on strengthening and mastery of foreign languages (Arabic and English). The development program is done internally and externally by having cooperation with outside agencies.

Strategies to guarantee the quality of graduates done through tight assessment, provision of extra programs that can improve the students' academic quality, continuous assessment, and the students' scientific work (thesis) must be written in either English or Arabic. Excellence program has a positive impact either on students who want to continue to pursue higher education or students who choose to work. The graduates of excellence programs are also mentally tough as well as have a high work ethic. 


\section{BIBLIOGRAPHY}

Alfian, E. (2011). Dampak sertifikasi guru terhadap peningkatan mutu proses pembelajaran: Studi kasus di MAN Model Jambi. Media Akademia, 26(2), 278-295. Retrieved from https://bit.ly/2MqVWFt

Barnett, R. (1992). Improving higher education: Total quality care. 1900 Frost Rd., Suite 101, Bristol, PA 19007: Open University Press.

Beare, H., Caldwell, B. J., \& Millikan, R. H. (2018). Creating an excellent school: Some new management techniques. Routledge.

Bogdan, R. C., \& Taylor, S. J. (1992). Pengantar metode penelitian kualitatif. Translation by Arief Furchan. Surabaya: Usaha Nasional.

Burnham, J. W. (1997). Managing quality in school: Effective strategies for quality based school improvement. London: Prantice Hall.

Carter, D. J. (2004). Affirming diversity: The sociopolitical context of multicultural education. Harvard Educational Review, 74(4), 465.

Cronbach, L. J. (2000). Evaluation models. In Course improvement through evaluation. Dordrecht: Springer.

Darling-Hammond, L., \& Lieberman, A. (2013). Teacher education around the world: Changing policies and practices. Routledge.

Scheme for Academic Mobility and Exchange. Direktorat Jenderal Sumber Daya IPTEK dan Pendidikan Tinggi Kementerian Riset, Teknologi, dan Pendidikan Tinggi 2017.

Findlow, S. (2006). Higher education and linguistic dualism in the Arab Gulf. British Journal of Sociology of Education, 27(1), 19-36. https://doi.org/10.1080/01425690500376754

Fitri, A. Z. (2013). Manajemen kurikulum pendidikan Islam. Bandung: Alfabeta.

Fitri, A. Z. (2016). Quality Assurance system between the Islamic State University and the State University. Jurnal Pendidikan Islam, 2(2), 208-230. https://doi.org/DOI: https://doi.org/10.15575/jpi.v2i2.787

Fullan, M., \& Pomfret, A. (1977). Research on curriculum and instruction implementation. Review of educational research, 47(2), 335-397. https://doi.org/10.3102/00346543047002335

Herliana, L. (2003). Isu-isu aktual sekolah dalam dunia pendidikan. Bandung: PPPGF.

Heryanto, E., \& Mabnun, B. N. (1993). Pengendalian mutu terpadu. Jakarta: Pustakan Binaman Pressindo. Gramedia.

Idrus, I. (1999). Towards quality higher education in Indonesia. Quality Assurance in Education, 7(3), 134-141. https://doi.org/10.1108/09684889910281566

House of Representatives of the Republic of Indonesia. The Law of the Republic of Indonesia Number 14 Year 2005 on Teachers and Lecturers.

Maimun, \& Fitri, A. Z. (2010). Madrasah unggulan: Lembaga pendidikan alternatif di era kompetitif. Malang: UIN Press.

Makondo, L., \& Ndebele, C. (2014). University lecturers' views on student-lecturer evaluations. The Anthropologist, 17(2), 377-386. Retrieved from https://www.researchgate.net/ publication/289060726_University_Lecturers'_Views_on_Student-Lecturer_Evaluations

Mitchell, B. M. (1969). Small class size: A panacea for educational ills? Peabody Journal of Education, 47(1), 32-35. https://doi.org/10.1080/01619566909537672

Mostafa, G. M. (2007). Correcting the image of Islam and Muslims in the West: Challenges and opportunities for Islamic universities and organizations. Journal of Muslim Minority Affairs, 27(3), 371-386. https://doi.org/10.1080/13602000701737210

Ogunsanya, M. E., Bamgbade, B. A., Thach, A. V., Sudhapalli, P., \& Rascati, K. L. (2018). Determinants of health-related quality of life in international graduate students. Pharmacy Teaching and Learning, 10(4), 413-422. https://doi.org/10.1016/j.cptl.2017.12.005 
Okwu, O. J. (2006). A critique of students' vices and the effect on quality of graduates of Nigerian tertiary institutions. Journal of Social Sciences, 12(3), 193-198. https://doi.org/10.1080/09718923.2006.11978391

Ramirez, G. B., \& Berger, J. B. (2014). Ranking, accreditation, and an international quest for quality: Organizing an approach to value in higher education. Quality Assurance in Education, 22(1), 89-100. https://doi.org/10.1108/QAE-07-2013-0031

Syahputra, H. (2013). Developing competitiveness and quality assurance in da'wa and communication faculty, Islamic State University Ar Raniry. Jurnal Al-Bayan, 19(27), 77-92. http:/ / dx.doi.org/10.22373/albayan.v19i27.99

Trott, J. R. (1963). Lectures, lecturers, and the lectured. Improving College and University Teaching, 11(2), 72-75. https://doi.org/10.1080/00193089.1963.10532218

Waridjan et.al. (1984). Pengembangan kurikulum dan sistem instruksional. Jakarta: Depdikbud. 